\title{
Anti-tumor necrosis factor (TNF) drugs for the treatment of psoriatic arthritis: an indirect comparison meta-analysis [Corrigendum]
}

Thorlund K, Druyts E, Aviña-Zubieta JA, et al. Biologics:

Targets and Therapy. 2012;6:417-427.

On page 418, note that under Search strategy, MerckShire-Dome should have been listed as Merck, Sharp, and Dohme.

On page 421, Figure 2, the relative risk for golimumab versus placebo for the PsARC response was incorrectly listed as
2.45, and should be 3.45. The mean difference for etanercept versus placebo for the PASI response was incorrectly listed as 2.13, and should be 3.13. The $\mathrm{x}$-axis of the PASI forest plot was incorrectly labeled with mean difference values of $1,2,3$ and 4 . The correct values are 3,6,9 and 12 .

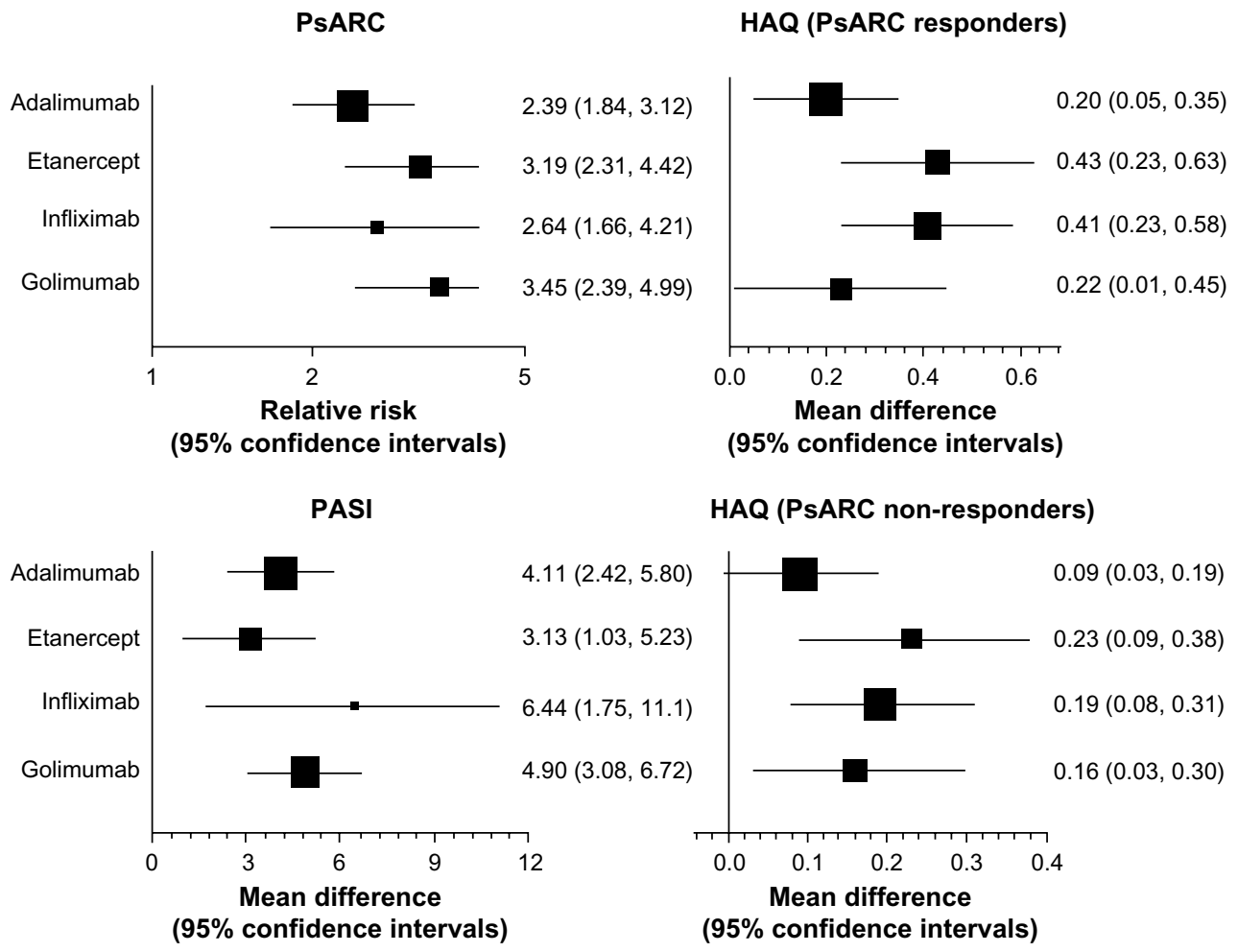

Figure 2 Forest plots of direct estimates for anti-TNFs versus placebo comparisons.

Abbreviations: anti-TNF, anti-tumor necrosis factor; HAQ, Health Assessment Questionnaire; PASI, Psoriasis Area and Severity Index; PsARC, Psoriatic Arthritis Response Criteria.

\section{Publish your work in this journal}

Biologics: Targets \& Therapy is an international, peer-reviewed journal focusing on the patho-physiological rationale for and clinical application of Biologic agents in the management of autoimmune diseases, cancers or other pathologies where a molecular target can be identified This journal is indexed on PubMed Central, CAS, EMBase, Scopus and the Elsevier Bibliographic databases. The manuscript management system is completely online and includes a very quick and fair peerreview system, which is all easy to use. Visit http://www.dovepress. com/testimonials.php to read real quotes from published authors. 